\title{
Based on the influence of financial innovation development on the financing of science and innovation enterprises
}

\author{
Bingqian $\mathrm{Bai}^{1 *}$ \\ ${ }^{1}$ Xinyang Normal University
}

\begin{abstract}
In recent years, the banking industry has constantly innovated the current financing methods and changed the service mode, namely, "investment linkage", "equity pledge", "intellectual property pledge" and other innovative financial service modes, which provide financial support for some scientific and innovative enterprises to carry out financing and so on. Therefore, it can be seen that the development of financial innovation has a positive impact on promoting the financing of science and technology innovation-oriented enterprises. On the basis of achieving a win-win situation, it injects new opportunities into the country's economic development. This paper makes an in-depth analysis and exploration on this issue.
\end{abstract}

\section{Introduction}

Science and innovation enterprises play an important role in realizing China's science and technology innovation and strengthening national strength. However, science and innovation enterprises, especially some small enterprises, are faced with some problems in the development process: large capital gap, lack of personnel, limited innovation ability, financing difficulties, etc., which limit the development of science and innovation enterprises. With the change of internal and external environment, the original financing method is difficult to meet the development of enterprises. Under such circumstances, science and innovation enterprises keep making changes to get rid of the current financing problem by improving their innovation ability.

\section{The concept and definition of scientific innovation enterprises and financial innovation}

Science and innovation enterprises mainly refer to enterprises with certain product technology content and product competitiveness, and other enterprises are difficult to copy and imitate. In the investment and development, we should put more new products into the market, and constantly occupy the market. Financial innovation mainly refers to the transformation of the original financial system or finance

Tools and other changes and adjustments to meet the needs of the market, to obtain more profits. Financial innovation and development can provide a variety of new financial products for more customer groups. According to the financing situation of science and innovation enterprises, the development of financial innovation is mainly reflected in the pertinence of products, that is, it can provide more financial services for science and innovation enterprises, such as "investment linkage", "equity pledge", "intellectual property pledge" and other innovative financial technology service modes. These services can provide an important guarantee for the financing of science and innovation enterprises and provide scientific and technological support.

\section{Analysis of the financing status of science and innovation enterprises}

\subsection{Problems existing in science and innovation enterprises themselves}

First of all, if science and innovation enterprises bear a heavy burden and their operating costs are high, the main reason is that labor costs, material costs, energy costs, raw materials or machinery and equipment costs are getting higher and higher. If the management is not good, it is easy to lose money.

Secondly, there is a lack of high-quality talents, mainly because small and micro enterprises based on science and technology mainly employ scientific and technological personnel. If the internal personnel lack innovation ability or cannot meet the requirements of these personnel in terms of remuneration, more talents will be lost.

Finally, from the situation of technology research and development, it can be seen that the whole process of product research and development needs to invest a lot of capital. Therefore, many enterprises are short of capital and innovation motivation, so it is more difficult for them to carry out financing. 


\subsection{Problems existing in the banking institution itself}

Apart from their own problems, technology-oriented enterprises find it difficult to raise more funds from banks and other financial institutions, which is also closely related to the banking institutions themselves. (1) Technological innovation of enterprise assets mainly to intellectual property rights and patents and other intangible assets, only a small number of banks in providing financial services to consider the intangible assets of the mortgage; (2) technology innovation enterprises of real estate is less, and rarely for mortgage, which is also a lot of guarantee companies are not willing to give technology innovation enterprises as a guarantee after weighing. Some financial institutions are not willing to provide financing services to science and innovation enterprises, that the financing services need to bear a greater risk, once these risks will make themselves into a greater dilemma.

\subsection{The influence of the government}

At the present stage, China's science and technology innovation enterprises in the tax burden on the larger, the government should increase the support of science and technology innovation enterprises, its main shortcomings are: (1) the government guarantee mechanism is not sound, the lack of venture funds; The main financing platforms for science and innovation enterprises are the New Third Board and GEM, but these two financing platforms have many restrictions. For example, the GEM has relatively strict requirements on capital and personnel of enterprises. In the actual work process, many small science and innovation enterprises cannot meet the requirements of the GEM.

\section{Analysis and introduction of fintech products}

\subsection{Linkage of investment}

This new type of financial support has become an important guarantee for the development of science and innovation enterprises. At the present stage, commercial banks have adjusted their main customer structure in investment and provided many small and medium-sized enterprises with financial services. Commercial banks will also develop credit plans in accordance with some regulatory requirements for scientific and creative enterprises and actively carry out businesses such as financing by pledging intellectual property rights. However, from the perspective of current science and innovation enterprises, their financing gap is relatively large. In order to promote the comprehensive development of science and innovation enterprises, the CBRC and banks initiated the pilot work on the linkage of investment in science and innovation enterprises as early as 2016, actively encouraging banks and financial institutions to provide more financial financing services to science and innovation enterprises. At the same time, the linkage of investment can also bring capital support for science and innovation enterprises in different cycles, which continuously improves the financial supply quantity of science and innovation enterprises, optimizes the structure of financial supply, and innovates, develops and effectively promotes the business of financial institutions

\subsection{Venture capital investment}

Venture capital is also known as venture capital, which is mainly invested in some emerging industries and high and new technologies with fast development speed. In 1950, The Japanese government also vigorously promoted venture capital, which enabled the Japanese government to occupy a major position in the world by virtue of its own high-tech in the society at that time. Some of the computer industry, Internet and semiconductor Kechuang Enterprise

by means of risk investment has obtained certain financing capital, these enterprises effectively promoted the development of new technology and new product development of industries, such as, but for leading enterprises, Kechuang Enterprise mainly rely on technology for obtaining the competition advantage of the market, if these $\mathrm{k}$ Kechuang Enterprise to develop customer satisfaction products of science and technology, it will give itself and even lead to the development of the industry.

Under the background of "mass entrepreneurship and innovation", Venture capital enterprises in China have achieved rapid development. Science and innovation enterprises need to adopt diversified strategies in the financing process and take possible risks into consideration when undertaking venture capital investment, which can help venture capital enterprises to achieve sustainable development.

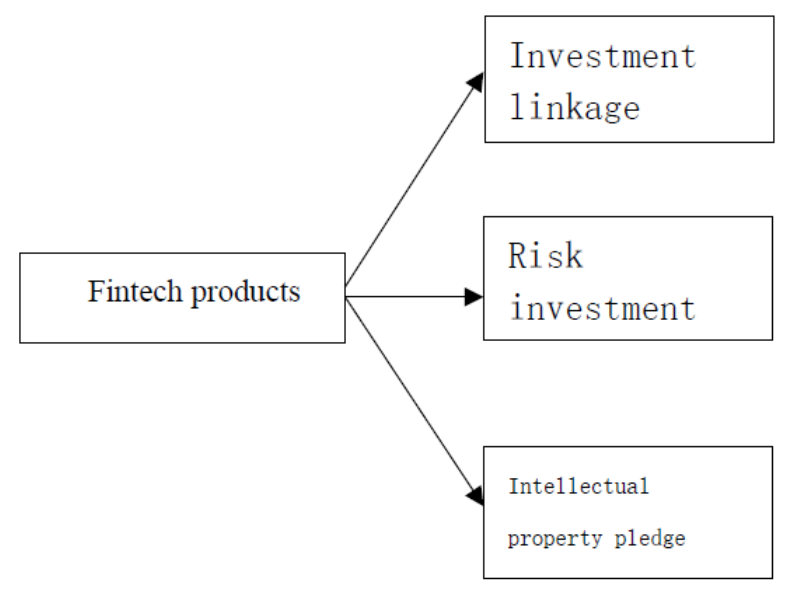

Fig.1. Fintech products

\section{Important paths for the financing development and financial innovation of science and innovation enterprises}
5.1 To find out the financial service mode suitable for the development of science and innovation enterprises 
In the strategy of innovative development, the integration of finance and science and technology should be realized, so as to lay a solid foundation for national development while realizing a win-win situation for both sides and help China to walk out a road of scientific and technological development. In China, due to the influence of its own mechanism, system or innovation ability, it is still very different from the powerful country in science and technology. The r\&d cycle of scientific and technological innovation is relatively long, and it also needs more capital, and the risk requirement is relatively high, while different scientific and technological innovation enterprises have different capital requirements. Therefore, in terms of product innovation and service innovation, China's financial institutions should give priority to demand, actively develop appropriate mechanisms and systems, and establish a financial service model that can promote the development of science and innovation enterprises.

\subsection{Strengthening fintech supervision and improving the financing environment}

The construction of regulatory system can maintain the fintech environment. Relevant Chinese government departments should formulate regulatory rules and technical standards related to fintech, so as to make the financing process of science and innovation enterprises and financial institutions more transparent. On the one hand, the regulatory authorities should change their previous regulatory thinking and take the initiative to regulate Internet fintech innovation. On the other hand, the fintech credit system should be established to strengthen the disclosure of relevant information. In particular, advanced technologies such as big data should be used to carry out early warning and effective monitoring of some illegal financial activities, so as to improve China's fintech supervision system.

\subsection{Providing more professional scientific and technological personnel and financial personnel}

Financial institutions are mainly targeted at science and innovation enterprises. For such enterprises, they need to strengthen relevant knowledge reserve in terms of professional knowledge and business ability, so as to provide manpower for the development of fintech innovation

The guarantee. On the one hand, financial institutions need to assess the professional technical background, ability and accomplishment of financial talents when selecting relevant talents. On the other hand, strengthen the training of existing technical personnel, so as to fully understand the high-tech industry knowledge and the current market trends. In addition, banks can also adopt the "order-type" training mode. After strengthening the cooperation with colleges and universities, banks can inject some knowledge about the development of high and new technology into financial majors, so as to comprehensively promote the development of financial innovation.

\subsection{Further strengthen government support and strengthen guarantee institutions to provide services for science and innovation enterprises}

On the one hand, in view of the small scale of some financing guarantee institutions, a guarantee alliance should be established for the purpose of sharing the related risks together and minimizing the guarantee risks of the guarantee institutions after the mutual allocation of losses. On the other hand, increase financial support. For example, for some local governments to increase the principal of guarantee institutions, increase the guarantee funds, through the integration of funds, under the role of financial leverage to provide more guarantees for science and innovation enterprises.

\subsection{To improve the management of science and innovation enterprises}

Kechuang Enterprise problems are mainly in the process of development, the difficulty of financing, the need to obtain from the following several aspects: on the one hand, to change the current management style, the pursuit of advancing with The Times, to promote the development of type Kechuang Enterprise to improve its research and development ability, such as after knowing to consumer preferences, can for the enterprise to develop more competitive products. On the other hand, innovation in business philosophy. Operators not only need to pay attention to the immediate profits, but also should have the concept of sustainable development, in the credit, management system should be continuously optimized.

This is mainly because science and innovation enterprises need to disclose relatively complete and true information before and after financing, so as to enable the investment units to fully understand the development situation of the enterprise, and then make effective judgments based on such information. Therefore, science and innovation enterprises need to solve the problem of information asymmetry when they are constantly improving their operation. Firstly, a feasible financial management system should be established. Secondly, improve staff quality and reduce information asymmetry.

\section{Conclusion}

For science and innovation enterprises, if they want to improve financing efficiency, they should pay enough attention to financial innovation, conduct in-depth analysis of the problems in the financing process, and alleviate financing difficulties by improving management, innovating financial service mode and improving staff quality.

\section{References}

1. Liu Zhijian. 2017 Fintech Report -- Industry Development and Legal Frontier [M]. Beijing: Law Publishing House, 2017.

2. Jay D. Wilson, Jr. Fintech -- Fintech defines future business value [M]. Beijing: People's Posts and 
Telecommunications Publishing House, 2018.

3. Li Wenhong, JIANG Zesheng. FinTech Development and Regulation: A Regulator's Perspective [J]. Financial Regulation Research, 2017, (3) : 1-13

4. Sun Haimei. Research on financial Support for the Development of China's Innovative smes [D]. Changchun: Jilin University, 2011.

5. Ma Qiujun. An Analysis of Financing Difficulties and Solutions for Technology-based smes in China [J]. Scientific Management Research, 2013, (4) : 113-116.

6. Research Group, Guangzhou Branch, People's Bank of China. Comparison and Enlightenment of The Development of Fintech between China and America [J]. Southern Finance, 2017, (5).

7. Tadesse S. . Consolidation, Scale Economies and Technological Change in Japanese Banking [J]. Journal of International Fi-nancial Markets, Institutions and Money, 2006, (5).

8. Li Sensen, Zhang Yuming. Research on the Construction of Growth Mechanism of Small and Micro Science and Technology Enterprises -- Based on the Theory of Enterprise Growth [J]. Shandong Social Science, 2014, (1) : 134-138.

9. Ji Jianqiang, Chen Xiaohe. Research on the Causes and Countermeasures of Financing Difficulties for Small and Micro Science and Technology Enterprises [J]. Science and Technology Progress and Countermeasures, 2014, (1) : 111-116 